\title{
Mariola Jaworska
}

Uniwersytet Warmińsko-Mazurski, Olsqtyn

\section{UCZEŃ ZE SPECYFICZNYMI TRUDNOŚCIAMI W UCZENIU SIĘ W PROCESIE UCZENIA SIĘ I NAUCZANIA JĘZYKÓW OBCYCH W POLSCE}

\section{Learners with specific learning difficulties in the process of learning and teaching foreign languages in Poland}

The article addresses the problem of teaching foreign languages to children and adolescents with particular learning difficulties, which require specialized help from the state and the school as an institution. The discussion includes the analysis of the current legal situation as well as the analysis of the organization and functioning of schools and psychologicalpedagogical counseling service.

\section{Wprowadzenie}

Uczeniu się, także uczeniu się języków obcych, zawsze towarzyszą trudności, niepowodzenia, które trzeba pokonywać. Oprócz tych, które pojawiają się niejako naturalnie, w procesie uczenia się występują także problemy specyficzne, o wąskim zakresie, dotyczące rozwoju funkcji biorących udział w czytaniu i pisaniu - określane powszechnie jako dysleksja rozwojowa.

Zgodnie z najczęściej cytowaną definicją ogłoszoną w 1994 r. przez Towarzystwo im. Ortona (Orton Dyslexia Society) dysleksja jest specyficznym zaburzeniem o podłożu językowym, jednym z wielu różnych rodzajów trudności w uczeniu się. Charakteryzuje się problemami w dekodowaniu pojedynczych słów, co najczęściej jest wynikiem niewystarczających zdolności przetwarzania fonologicznego. Problemy te są zazwyczaj niewspółmierne do wieku oraz poziomu innych zdolności poznawczych i umiejętności szkolnych (za: Bogdanowicz 2004: 84). Specyficzne trudności w uczeniu się diagnozuje się na podstawie charakterystycznych objawów, w sytuacji, gdy dziecko posiada dobra 
sprawność intelektualną, a jego problemy nie wynikają z zaniedbań dydaktycznych i/lub środowiskowych.

Dysleksja rozwojowa jest zespołem zaburzeń włączonym do Międzynarodowej Klasyfikacji Zaburzeń Opanowania Umiejętności Szkolnych (ICD-10 z 1992 roku oraz DSM-IV z 1994 roku). U jej podłoża leżą zakłócenia rozwoju funkcji percepcyjno-motorycznych: analizy i syntezy wzrokowej, analizy i syntezy słuchowej, motoryki, integracji ww. procesów, pamięci wzrokowej, słuchowej, ruchowej, lateralizacji, orientacji w schemacie ciała.

Formy, jakie może przyjąć dysleksja rozwojowa to:

- dysleksja (w wąskim rozumieniu) - specyficzne trudności w opanowaniu umiejętności czytania,

- $\quad$ dysgrafia - specyficzne trudności w opanowaniu poziomu graficznego pisma,

- dysortografia - specyficzne trudności w opanowaniu poprawnej pisowni (w tym popełnianie błędów ortograficznych) (Bogdanowicz 2004: 81).

Symptomy dysleksji rozwojowej moga pojawić się na każdym etapie rozwoju, najczęściej jednak występują od początku nauki szkolnej i najlepiej, gdyby wówczas zostały zdiagnozowane. W sytuacji zauważenia objawów wskazujących na zagrożenie dysleksją (najwyraźniejsze są one w wieku przedszkolnym) mówi się o „ryzyku dysleksji”. Sformułowanie to może być stosowane do klasy drugiej szkoły podstawowej. Gdy objawy pogłębiają się i obejmują coraz więcej sfer rozwojowych, dziecko ryzyka dysleksji staje się uczniem z dysleksją (Bogdanowicz 2004: 86; Bogdanowicz i in. 2008: 9).

Badania naukowe (Jurek 2004: 102) wskazuja, że uczniowie z dysleksją rozwojową - pomimo dobrej sprawności intelektualnej i systematycznej pracy terapeutycznej - mają duże trudności z nauką języka obcego, które występują u nich częściej niż u osób niedyslektycznych. Kłopot może sprawiać m.in. różnicowanie głosek zbliżonych fonetycznie, wypowiadanie niektórych głosek, różnicowanie wyrazów podobnie brzmiących, powtarzanie dłuższych i trudniejszych słów. Nie wszystkie języki obce sprawiają uczniom takie same problemy, ważny jest więc wybór języka obcego.

\section{Uczniowie ze specyficznymi trudnościami w uczeniu się w polskiej rzeczywistości edukacyjnej}

Analizując sprawozdania z osiagnięć uczniów przedstawiane corocznie przez Centralną Komisję Egzaminacyjną (CKE), można stwierdzić, że specyficzne trudności w uczeniu się występują u ok. 10\% uczniów polskich szkół. W latach 2008-2010 z dostosowania warunków i form sprawdzianu oraz egzaminu gimnazjalnego skorzystało w 2008 r. - 9,0\%, w 2009 r. - 9,01\% i w 2010 r. 9,13\% uczniów szkół podstawowych oraz w 2008r. - 9,3\%, w 2009 r. - 9,3\% i w 2010 r. - 8,9\% gimnazjalistów (CKE 2010a; CKE 2010b). O ile nie wzbudza wątpliwości ogólna liczba tych uczniów, ponieważ uznaje się, że dysleksja występuje u 10\% populacji, o tyle zdziwienie i niepokój budzi nierówny rozkład 
udziału uczniów ze specyficznymi trudnościami w uczeniu się zaznaczający się w poszczególnych województwach - np. w 2010 r. od 5,9\% (opolskie) do 15,2\% (pomorskie) w przypadku sprawdzianu oraz od 6,0\% (wielkopolskie) do 15\% (pomorskie) na egzaminie gimnazjalnym. Wyraźne zróżnicowanie rozkładu występowania uczniów dyslektycznych zauważalne jest też w powiatach (od 0,8\% do 32,7\% populacji uczniów w roku 2008) (CKE 2008). Przyczyną takiego stanu rzeczy może być nierówny dostęp do diagnozy psychologicznopedagogicznej, niski poziom wiedzy na temat dysleksji rodziców/opiekunów dzieci z małych miejscowości, ale także działalność na danym terenie ośrodków zajmujących się wspieraniem uczniów ze specyficznymi trudnościami w uczeniu się, np. oddziałów Polskiego Towarzystwa Dysleksji.

Z powyższych danych wynika, że właściwie w każdej klasie możemy spotkać dziecko z dysleksja rozwojowa, a nauczyciele - także nauczyciele języków obcych - coraz częściej mają do czynienia z uczniami, którzy wymagają specjalistycznego wsparcia. Jednocześnie rosną ogólnokrajowe wymagania, aby wszystkie dzieci uczyły się języków obcych. Zgodnie z nową podstawą programową wychowania przedszkolnego i kształcenia ogólnego (Rozporządzenie A) nauka pierwszego języka obcego rozpoczyna się w pierwszej klasie szkoły podstawowej, obowiązkowa nauka drugiego w gimnazjum. Język obcy jest częścią egzaminu gimnazjalnego i maturalnego, za kilka lat będzie też elementem sprawdzianu.

Biorąc pod uwagę odsetek uczniów z dysleksją rozwojową w polskich szkołach, warto zastanowić się nad tym, jaki jest aktualny stan prawny dotyczacy nauczania - także języków obcych - dzieci i młodzieży ze specyficznymi trudnościami w uczeniu się, jak wygląda rzeczywista organizacja specjalistycznej pomocy i wsparcia takich uczniów na płaszczyźnie szkoły i poradni psychologiczno-pedagogicznych oraz czy aktualne rozwiązania w tym zakresie sa wystarczające.

Przełomem w podejściu do uczniów ze specjalnymi potrzebami edukacyjnymi, do których zalicza się także uczących się ze specyficznymi trudnościami w nauce, była ustawa o systemie oświaty z 7 września $1991 \mathrm{r}$. (tekst jednolity, Dz.U. z 2004 r. Nr 256, poz. 2572, z późn. zm.), która zagwarantowała:

- realizację prawa każdego obywatela Rzeczypospolitej Polskiej do kształcenia się oraz prawa dzieci i młodzieży do wychowania i opieki, odpowiednich do wieku i osiągniętego rozwoju,

- dostosowanie treści, metod i organizacji nauczania do możliwości psychofizycznych uczniów, a także możliwość korzystania z pomocy psychologiczno-pedagogicznej i specjalnych form pracy,

- możliwość pobierania nauki we wszystkich typach szkół, zgodnie z indywidualnymi potrzebami rozwojowymi i edukacyjnymi oraz predyspozycjami. 
Wprowadzone na mocy tej ustawy rozporządzenia (Rozporządzenia B, C, D, E, F) reguluja kwestie dotyczace praw ucznia, organizacji pomocy psychologicznopedagogicznej oraz warunków i form kształcenia w szkołach. Na mocy tych dokumentów uczniowie ze specyficznymi trudnościami w nauce mają prawo do:

- uzyskania opinii bądź orzeczenia w sprawach dostosowania wymagań edukacyjnych do ich indywidualnych potrzeb psychofizycznych i edukacyjnych,

- zwolnienia - w przypadku głębokiej dysleksji rozwojowej - z nauki drugiego języka obcego; zwolnienie może dotyczyć części lub całego okresu kształcenia w danym typie szkoły,

- wczesnej diagnozy i specjalistycznej interwencji (dostosowania programu i metod do potrzeb i możliwości, nauki w klasach terapeutycznych, dostępu do poradnictwa i zajęć psychoedukacyjnych),

- udziału w zajęciach korekcyjno-kompensacyjnych, prowadzonych przez nauczycieli posiadających przygotowanie w zakresie terapii pedagogicznej (liczba uczestników zajęć wynosi od 2 do 5),

- dostosowania wymagań szkolnych i sposobu oceniania do ich możliwości,

- przystapienia do egzaminów zewnętrznych w warunkach i formie dostosowanych do indywidualnych potrzeb.

Dostosowanie, którego sposób określa Dyrektor Centralnej Komisji Egzaminacyjnej w specjalnych komunikatach, może mieć charakter merytoryczny, np. modyfikacja kryteriów oceniania arkuszy, lub formalny: wydłużenie czasu, możliwość zapisywania odpowiedzi za pomocą komputera lub pomoc nauczyciela, który zapisuje odpowiedzi w przypadku ucznia z dysgrafią lub głośno odczytuje informacje, teksty i treści zadań w przypadku ucznia z dysleksją właściwa.

Do obowiązków poradni psychologiczno-pedagogicznych należy m.in.

- udzielanie dzieciom, młodzieży, rodzicom i nauczycielom pomocy psychologiczno-pedagogicznej poprzez: diagnozę, konsultację, terapię zaburzeń rozwojowych, psychoedukację, doradztwo, działalność informacyjna,

- wspomaganie wszechstronnego rozwoju dzieci i młodzieży, efektywności uczenia się,

- wydawanie opinii w sprawach m.in. objęcia ucznia nauką w klasie terapeutycznej, dostosowania wymagań edukacyjnych wynikających z programu nauczania do indywidualnych potrzeb ucznia, zwolnienia ucznia z głęboką dysleksją rozwojową z nauki drugiego języka obcego, przystapienia ucznia lub absolwenta ze specyficznymi trudnościami w uczeniu się do sprawdzianu przeprowadzanego w szkole podstawowej, egzaminu gimnazjalnego, egzaminu maturalnego lub egzaminu zawodowego, w warunkach i formie dostosowanych do indywidualnych potrzeb psychofizycznych ucznia lub absolwenta.

Szkoła i nauczyciele są zobowiązani: 
Uczeń ze specyficznymi trudnościami w uczeniu się w procesie uczenia się i ...

- realizować i uwzględniać wskazania zawarte w opinii poradni psychologiczno-pedagogicznej,

- dostosować wymagania edukacyjne do indywidualnych potrzeb psychofizycznych i edukacyjnych ucznia, u którego stwierdzono specyficzne trudności w uczeniu się, uniemożliwiające sprostanie tym wymaganiom,

- organizować zajęcia rewalidacyjne i korekcyjno-kompensacyjne,

- przeprowadzać wielospecjalistyczną ocenę poziomu osiagnięć nie rzadziej niż raz $\mathrm{w}$ roku $\mathrm{w}$ celu opracowania i modyfikowania indywidualnego programu edukacyjnego,

- $\quad$ wyrównywać szanse edukacyjne przez profilaktykę niepowodzeń szkolnych.

Wydawać mogłoby się więc, że przedstawione powyżej rozwiązania instytucjonalne reguluja kwestię funkcjonowania i wsparcia uczniów ze specyficznymi trudnościami w uczeniu się w polskim systemie oświaty, a dzieci i młodzież mają zapewnione indywidualne, specjalistyczne wsparcie. Jednak w praktyce pomoc udzielana jest w niepełny sposób i nie obejmuje wszystkich uczniów, co sygnalizują autorzy raportów i badań na ten temat.

Badania przeprowadzone w województwie łódzkim wśród 548 uczniów (Weiner 2008) wykazały, że po zdiagnozowanej dysleksji na zajęcia terapeutyczne, które odbywały się najczęściej w szkołach, rzadziej w poradniach, uczęszczało 59\% uczniów. Liczba ta po krótkim okresie trwającym od kilku tygodni do kilku miesięcy gwałtownie zmalała do 13\%. 39\% uczniów w ogóle nie brało udziału w zajęciach terapii pedagogicznej przewidzianej dla uczniów z zaburzeniami funkcji percepcyjno-motorycznych, gdyż, jak twierdzili, nie zaproponowano im takiej formy lub nie wiedzieli o możliwości uczęszczania na tego typu ćwiczenia. Badania wykazały także, że wielu uczniów (36\%) nie widzi potrzeby uczęszczania na zajęcia i nie docenia ich wartości.

Jeśli zajęcia korekcyjno-kompensacyjne sa już w szkołach prowadzone, to najczęściej raz w tygodniu w wymiarze 1 godziny, co jest wynikiem braku kadry wykwalifikowanej w zakresie terapii pedagogicznej oraz wystarczających środków finansowych. Zazwyczaj obejmują wyłącznie uczniów na pierwszym etapie edukacyjnym $z$ wyłączeniem klas starszych. Niezadowalający jest stan wiedzy i umiejętności nauczycieli, którzy deklarują np., że wiedzą, czym jest dysleksja, podczas gdy nie potrafią wymienić konkretnych zaburzeń i ich przyczyn. Chociaż zauważaja potrzebę indywidualizacji pracy z uczniami ze specyficznymi trudnościami w uczeniu się, $60 \% \mathrm{z}$ nich nie zna form i metod pracy pedagogicznej (Gal, http://konferencja.21.edu.pl/publikacje/1/51.pdf). Należy zauważyć, że brak wiedzy i niewystarczające kompetencje nauczycieli powodują bezradność, a w konsekwencji bierność.

W poradnictwie psychologiczno-pedagogicznym także występuje wiele problemów wpływających niekorzystnie na realizację zadań i warunki funkcjonowania placówek. Biorąc pod uwagę dane przedstawiane przez Centrum Metodyczne Pomocy Psychologiczno-Pedagogicznej (CMPPP), można stwierdzić, 
że podstawę organizowania pomocy dzieciom i młodzieży ze specyficznymi trudnościami w uczeniu się przez poradnie psychologiczno-pedagogiczne stanowią formy pomocy pośredniej: orzekanie i opiniowanie, podczas gdy pomoc bezpośrednia w formie terapii jest realizowana w mniejszym zakresie (CMPPP 2009). Najpopularniejszymi i najczęściej wydawanymi opiniami są te dotyczące dostosowania wymagań edukacyjnych wynikających z programu nauczania do indywidualnych potrzeb edukacyjnych ucznia (26,59\% wszystkich opinii wydanych w 2008r.).

W opiniach, które wydawane są na wniosek rodziców, ucznia lub szkoły za zgodą rodziców, w odniesieniu do uczniów ze specyficznymi trudnościami w uczeniu się, zaleca się najczęściej:

- zmniejszyć ilość wymaganego materiału do nauczenia,

- operować tylko podstawowymi formami gramatycznymi,

- uwzględniać wolniejsze tempo uczenia się (dać więcej czasu niż innym uczniom na prace pisemne),

- oceniać efekty nauki na podstawie odpowiedzi ustnych,

- nie brać pod uwage błędów w zapisie wyrazów, jeśli treść i kompozycja tekstu są poprawne,

- organizować ćwiczenia korekcyjno-kompensacyjne,

- w przypadku głębokiej dysleksji rozwojowej zwolnić ucznia z nauki drugiego języka obcego.

Problemy w organizacji wsparcia uczniów ze specyficznymi trudnościami w uczeniu się, na jakie wskazuje raport CMPPP (CMPPP 2009), dotyczą następujących kwestii:

- brakuje stosownych uregulowań prawnych; rozporządzenia nie określają sposobu dostosowania wymagań edukacyjnych uczniom ze specyficznymi trudnościami w uczeniu się,

- mimo że w niektórych przedszkolach i szkołach pracują nauczyciele posiadający przygotowanie do prowadzenia specjalistycznych zajęć, właściwa pomoc psychologiczno-pedagogiczna nie jest organizowana (gdyż np. nie przyznaje się szkole środków finansowych na sygnalizowane przez nauczycieli niezbędne działania),

- liczba etatów w poradniach jest zbyt mała; brakuje możliwości zatrudnienia dodatkowej liczby specjalistów, co powoduje, że pomoc bezpośrednia, czyli np. różne formy terapii, mimo często wysokich kwalifikacji pracowników, są realizowane w mniejszym zakresie,

- w obszarze relacji między przedszkolami, szkołami a poradniami konieczne jest ulepszenie systemu współpracy poradni z psychologami szkolnymi.

\section{Zmiany projektowane w polskim prawie oświatowym dotyczące uczniów ze specyficznymi trudnościami w uczeniu się}


Ministerstwo Edukacji Narodowej przygotowało projekt zmian, dotyczący uczniów ze specjalnymi potrzebami edukacyjnymi, którego realizacja ma spowodować skuteczniejszą niż dotychczas pomoc m.in. dzieciom i młodzieży mającym specyficzne trudności w uczeniu się (MEN. 2010). Zaproponowany model zakłada:

- wprowadzenie obowiązku oceny dojrzałości szkolnej dziecka w wieku przedszkolnym,

- zobowiązanie szkoły podstawowej do rozpoznawania specyficznych trudności w uczeniu się na pierwszym etapie edukacyjnym, co pozwoli na wyeliminowanie przypadków zgłaszania się do poradni psychologicznopedagogicznych licealistów z prośbą o wydanie opinii potwierdzającej u nich dysleksję rozwojowa; opinia, wydawana na drugim etapie edukacyjnym, zachowywałaby ważność przez cały okres edukacji szkolnej,

- poszerzenie świadczonej pomocy psychologiczno-pedagogicznej o obowiązkowe prowadzenie obserwacji pedagogicznych,

- zobowiązanie poradni psychologiczno-pedagogicznych do udzielania wsparcia metodycznego i merytorycznego nauczycielom,

- zobowiązanie nauczycieli do współpracy z poradniami psychologicznopedagogicznymi oraz placówkami doskonalenia nauczycieli w zakresie podnoszenia swoich kompetencji zawodowych,

- zobowiązanie szkoły do opracowania i wdrożenia indywidualnego programu pracy z uczniem,

- zobowiązanie nauczycieli do indywidualizacji pracy z każdym uczniem, zarówno w ramach obowiązkowych, jak i dodatkowych zajęć (także w ramach godzin przeznaczonych na dodatkową pracę z uczniem, wprowadzonych art. 42 ustawy Karta Nauczyciela),

- zwiększenie kompetencji dyrektora szkoły w zakresie dostosowania warunków i form przeprowadzania sprawdzianów i egzaminów zewnętrznych,

- utworzenie w każdej szkole zespołu do spraw specjalnych potrzeb edukacyjnych uczniów, złożonego z nauczycieli i specjalistów zatrudnionych w szkole, który przynajmniej raz w roku, przy udziale rodziców ucznia, przedstawicieli organu prowadzącego szkołę oraz poradni psychologiczno-pedagogicznej oceniałby skuteczność świadczonej uczniowi pomocy oraz zatwierdzal zmiany w indywidualnych programach edukacyjnych,

- wprowadzenie dla każdego dziecka Karty Potrzeb i Świadczeń dokumentu, który wydawany przez poradnię psychologicznopedagogiczna, zawierałby m.in. diagnozę wynikającą z orzeczenia, opinii lub rozpoznania dokonanego przez nauczycieli i specjalistów na poziomie szkoły.

\section{Uwagi końcowe}


Podsumowując powyższą analizę, można zauważyć, że największym problemem rzeczywistości edukacyjnej, w której obecnie funkcjonują uczniowie ze specyficznymi trudnościami w uczeniu się, jest brak spójności pomiędzy działaniami szkoły, poradni psychologiczno-pedagogicznych i ucznia, a także niedostateczne monitorowanie losu oraz postępów dzieci i młodzieży po przeprowadzonej diagnozie.

Zalecane zazwyczaj w opiniach dostosowanie wymagań edukacyjnych kończy się najczęściej na formalnym obniżeniu bądź zwolnieniu ucznia z wymagań. Uczniowie i ich rodzice traktują je często wyłącznie jako dokument, który daje pewne przywileje - wydłużenie czasu na egzaminie, zmniejszenie wymagań edukacyjnych, inne kryteria oceniania - i czują się zwolnieni z dalszych zabiegów korygujących zaburzenia. Nie postrzegają ich jako zobowiazzania do pracy nad przezwyciężaniem trudności. Tymczasem, należałoby ściśle określić oczekiwania, podjąć działania terapeutyczne odpowiadające indywidualnym potrzebom ucznia, rozwijać $\mathrm{w}$ nim samodzielność, wiarę we własne siły i korygować zaburzone funkcje. Warunkiem realizacji tych celów jest kształcenie i doskonalenie się nauczycieli, którzy powinni posiadać rzetelną wiedzę na temat zaburzeń rozwojowych i możliwości ich uwzględniania w procesie dydaktycznym. Dzieci i młodzież ze specyficznymi trudnościami w uczeniu się wymagaja specjalistycznej pomocy, ale też motywowania i zobligowania do pracy. Konieczne jest zatem stworzenie mechanizmów umożliwiających im korzystanie $\mathrm{z}$ praw wynikających $\mathrm{z}$ właściwych rozporządzeń, ale także powiązanie diagnozy dysleksji $\mathrm{z}$ obowiązkiem podjęcia pracy na zajęciach $\mathrm{w}$ szkole i w domu.

Wydaje się też, że należałoby opracować krajowe standardy formułowania opinii o występowaniu dysleksji rozwojowej tak, aby na jej podstawie można było podjać konkretne działania mające na celu indywidualne korygowanie zaburzeń wynikających $\mathrm{z}$ dysfunkcji. Opinia o dysleksji powinna zawierać, obok konieczności dostosowania wymagań do potrzeb, wyraźne wskazówki dla nauczycieli, jak pracować z uczniem na lekcjach. Nauczanie języka obcego - uwzględniające postulaty współczesnej myśli glottodydaktycznej, takie jak np. rozwój autonomii ucznia, jego samodzielności, trening strategii uczenia się, potrzeba nauczania polisensorycznego - może być przecież ważnym czynnikiem stymulującym i ułatwiającym usprawnianie funkcji percepcyjno-motorycznych.

Ważną rolę w projekcie zmian przygotowanym przez MEN przypisuje się nauczycielowi. To on ma obserwować ucznia, postawić wstępną hipotezę, przeprowadzić diagnozę, zaplanować i realizować pomoc poprzez dostosowywanie treści, form i metod pracy. Dopiero wówczas, gdy nauczyciel wykorzysta wszelkie możliwości wsparcia na terenie szkoły czy przedszkola, uczeń będzie uczestniczył w zajęciach o charakterze terapii pedagogicznej prowadzonych w specjalistycznej poradni. Wydaje się jednak, że spełnienie tych 
oczekiwań przez nauczycieli nie będzie możliwe bez zbudowania systemu wsparcia ich przez specjalistów. W związku z tym nowe wyzwania pojawiają się także przed poradnictwem psychologiczno-pedagogicznym, co wiąże się z koniecznością stworzenia nowego modelu jego funkcjonowania. Będzie to wymagało wypracowania innych niż dotąd form współpracy pomiędzy podmiotami realizującymi pomoc: poradniami i szkołami, a w szkołach pedagogami, psychologami oraz nauczycielami.

\section{BIBLIOGRAFIA}

Bogdanowicz, M. 2004. „Niespecyficzne i specyficzne trudności w uczeniu się języków obcych”, w: Bogdanowicz, M., Smoleń, M. (red.). Dysleksja w kontekśsie nauczania jezyków obych. Gdańsk: Wydawnictwo Harmonia. 7897.

Bogdanowicz, M., Bućko, A., Czabaj, R. 2008. Modelowy system profilaktyki i pomocy psychologiczno-pedagogicznej uczniom z dysleksja. Gdynia: Operon.

Centralna Komisja Egzaminacyjna. 2008. Osiagniecia uczniów kończacych szkote podstawowa w roku 2008. Sprawozdanie ze sprawdzianu 2008. (http://www.cke.edu.pl/).

Centralna Komisja Egzaminacyjna. 2010a. Osiggnięcia uczniów kończacych gimnazjum w roku 2010. Sprawozdanie z. egzaminu gimnazjalnego 2010. (http://www.cke.edu.pl/).

Centralna Komisja Egzaminacyjna. 2010b. Osiagnięcia uczniów kończacych sqkote podstawowa $w$ roku 2010. Sprawozdanie ze sprawdzianu 2010. (http://www.cke.edu.pl/).

Centrum Metodyczne Pomocy Psychologiczno-Pedagogicznej. 2009. Publiczne poradnictwo psychologiczno-pedagogiczne wg danych z bazy systemu informacji oswiatowej (SIO) zebranych na dzien 30.09.2008 roku. (http://www.cmp3.ore.edu .pl/files/Publiczne\%20poradnictwo.pdf).

Gal, K. Usprawnianie dzieci z dysleksja w zreformowanej szkole. (http://konferencja.21 .edu.pl/publikacje/1/51.pdf). 51-55

Jurek, A. 2004. „Trudności w nauce języków obcych uczniów z dysleksją rozwojowa”, w: Bogdanowicz, M., Smoleń, M. (red.). Dysleksja w kontekście nauczania jezy/ków obych. Gdańsk: Wydawnictwo Harmonia. 98-116.

Ministerstwo Edukacji Narodowej. 2010. Ucznionie ze specjalnymi potrzebami edukacyjnymi. Założenia projek.towanych zmian. (http://www.konferencje.men.gov.pl/images/ pdf/Konferencje/3.pdf).

Rozporządzenie A: Rozporzqdzenie Ministra Edukacji Narodowej z. dnia 23 grudnia 2008 r. w sprawie podstawy programowej wychowania przedszkolnego oraz. kesztatcenia ogólnego w poszczególnych typach szkót (Dz. U. z 2009 r. Nr 4, poz: 17).

Rozporzadzenie B: Rozporzqdzenie Ministra Edukacji Narodowej i Sportu z dnia 11 grudnia 2002r. w sprawie szczególowych zasad driatania publicznych poradni psychologiczno-pedagogicznych, w tym poradni specjalistycznych (Dz. U. z 2003 r. Nr 5, poz. 46). 
Rozporządzenie C: Rozporzqdzenie Ministra Edukacji Narodowej i Sportu z dnia 7 stycznia 2003 r. w sprawie zasad udzielania i organizaci pomocy psychologicznopedagogicznej w publicznych przedszkolach, szkolach i placówkach (Dz. U. z 2003r. Nr 11, poz. 14).

Rozporządzenie D: Rozporzqdzenie Ministra Edukacji Narodowej i Sportu z dnia 18 stycznia 2005r. w sprawie warunków organizowania ksztatcenia, wychowania $i$ opieki dla drieci i mtodzieży niepetnosprawnych oraz niedostosowanych spotecznie w przedszkolach, szkołach $i$ oddziałach ogólnodostęnych lub integracyjnych (Dz.U. z 2005r. Nr 19, poz. 167).

Rozporządzenie E: Rozporzadzenie Ministra Edukacji Narodowej i Sportu z dnia 18 stycznia 2005r. w sprawie warunków organizowania ksztatcenia, wychowania $i$ opieki dla dzieci i młodzieży niepetnosprawnych oraz niedostosowanych społecznie $w$ specjalnych przedszkolach, szkołach $i$ oddziatach oraz $w$ ośrodkach (Dz.U. z 2005r. Nr 19, poz. 166).

Rozporzadzenie F: Rozporzqdzenie Ministra Edukacji Narodowej z dnia 30 kwietnia 2007r. w sprawie warunków i sposobu oceniania, klasyfikowania $i$ promowania uczniów $i$ stuchaczy oraz prepprowadzania sprawdzianów $i$ egzaminów w sqkołach publicznych (Dz. U. z 2007r. Nr 83, poz. 562, z późn. zm.).

Ustawa o systemie oświaty z. 7 września 1991 r. (tekst jednolity, Dz.U. z 2004r. Nr 256, poz. 2572 z późn. zm.).

Wejner, T. 2008. „Liczy się uczeń a nie statystyki - badania ankietowe dotyczące szkoły przyjaznej uczniom z dysleksją". (http://www.ptd-lodz.com/ uczniowie-dyslektyczni-ankieta.php). 